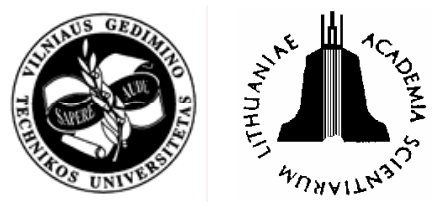

\title{
EXPERIMENTAL BEHAVIOUR OF REINFORCED CONCRETE COLUMN MODELS STRENGTHENED BY CFRP MATERIALS
}

\author{
Mieczysław Kamiński ${ }^{1}$, Tomasz Trapko ${ }^{2}$ \\ ${ }^{1,2}$ Institute of Building Engineering, Wrocław University of Technology, \\ Pl. Grunwaldzki 11, 50-370 Wrocław, Poland \\ E-mail: ${ }^{1}$ mieczyslaw.kaminski@pwr.wroc.pl; \\ ${ }^{2}$ tomasz.trapko@pwr.wroc.pl \\ Received 16 May 2005; accepted 17 Oct 2005
}

\begin{abstract}
Strengthening of the reinforced concrete structures is one of the most difficult and important tasks of civil engineering. The paper presents the problem of strengthening of reinforced concrete structures. Experimental tests of load-carrying capacity of reinforced concrete columns strengthened with CFRP strips and wraps have been carried out. The first objective of this research was to determine the influence of the type of reinforcement on load-carrying capacity and strain. The second objective was to determine interdependence of the intensity of external reinforcement and load-carrying capacity of element. Tests results have shown that the subject was worth investigating. Relations between external reinforcement ratio and load-carrying capacity of small models of RC columns with various reinforcement ratio (from $1,4 \%$ to $4,2 \%$ ) have been examined.
\end{abstract}

Keywords: column, compression, load-carrying capacity, strengthening, CFRP.

\section{Introduction}

Rehabilitation and strengthening of reinforced concrete structures is a dynamically growing division of structural engineering. In recent years an increased application of new repair and strengthening systems of reinforced concrete load-carrying structures has been noted.

The problem of strengthening the reinforced concrete structures appeared for the first time when their proper function was modified or they were used in a different manner than previously planned. Assumptions made in the design are closely connected with a specific function of the structure. The designers of the existing reinforced load-carrying structures constructed many years ago could not predict their use in practice and determine all deterioration effects produced by external factors during their service. It was not rare to find that in this way some structural members could be deteriorated or even damaged. In most cases the increased dead and live loading that should be safely carried by the structures, as well as their poor technical condition necessitate strengthening procedures.

Main reasons of structural strengthening are:

- increase of dead and live loading,

- material aging and corrosion,

- mechanical damage,

- reduction of strain limits,

- decrease of stress in steel reinforcement

- decrease of crack width,
- modification of structure static scheme,

- construction failures.

Strengthening of the reinforced concrete structures is one of the most difficult and important tasks of civil engineering. Individual approach to the problem is a necessity since any ready-made solution can be applied. One of the prime objectives is to provide detailed technical and cost-effective analyses. Structures must be carefully examined in order to determine their technical condition, to find reasons for deterioration and strengthening as well as to establish service requirements of the reinforced structures. It is also essential to analyse their technical design, dig out open pits and carry out suitable measurements. Cost-effectiveness of each of the proposed strengthening techniques should be considered and compared to the cost of a new structure. The strengthening methods applied should ensure the required safety margin and guarantee a sufficient reliability over time.

The following methods used for strengthening the reinforced concrete compressed columns can be distinguished according to their application way:

- increase of the cross-sectional area of a column,

- modification of the structural static scheme.

Conventional techniques using the increase of crosssectional area of a column comprise the following:

- additional longitudinal and transverse reinforcement and increased cross-sections embedded in reinforced concrete, 
- additional steel sections,

- adhesively bonded or bolted steel flat sections or sheet elements.

Modification of the structural static scheme is accomplished by means of additional steel columns or knee braces carrying the load directly to the foundation.

One of the state-of-the-art methods used for strengthening the structural members are those utilising carbon-reinforced composite materials such as strips, wraps, sheet elements or shapes. Over the last decade new alternative solutions are being developed for civil infrastructure applications to meet the growing demand since a conventional technology is known for its many shortcomings and limitations.

The increased applications of these materials to strengthening the reinforced concrete structures are due to their advantageous properties such as high strength, durability and high-fatigue resistance. A lightweight combined with an easy maintenance as well as short time of application make it a worthwhile alternative. The only significant disadvantage is a relatively high cost of materials. The strengthening elements themselves do not influence the size of a structure or adversely affect its aesthetics.

Taking into account a marked increase in the application of CFRP composites utilised to reinforced elements in bending and shear and their advantageous properties, such as an easy maintenance and competitiveness, it was proposed to use CFRP strips and wraps for strengthening the structural elements in compression. For several years the research on the compression reinforced concrete columns strengthening with FRP composites have been carried out. The abovementioned technology is novel, thus many scientific centres worldwide have been trying to find satisfactory answers to the arising problems. With precursors of this studies were aggregates directed by Priestley [1], Saadatmanesh [2], Demers and Neale [3] and Picher [4]. The satisfactory results obtained in these studies have inspired other scientific centres in the world [5-9] as well as in Poland $[10,11]$ to embark on further research of this subject.

The research objective was to evaluate the influence of the following parameters on the strength of the column models:

- the stiffness of the confinement (different numbers of FRP sheets) [3, 8, 10],

- the kind of the FRP materials (AFRP, GFRP, CFRP) $[3,8]$,

- the shape of the section (different corner radius) [3, $8,10]$

- the compressive strength of concrete $[3,6]$,

- strengthening after "damaged loading" [6],

- eccentric loading [7, 10].

In order to prove the effectiveness of strengthening the reinforced concrete columns in compression with longitudinal CFRP strips and transverse CFRP wraps some studies were conducted at the Institute of Building Engineering, Wroclaw University of Technology [1215]. One of the objectives of this study was to acquire essential knowledge concerning the influence of slenderness and eccentricity on strain and strength abilities as well as to describe the damage mechanisms of structural elements.
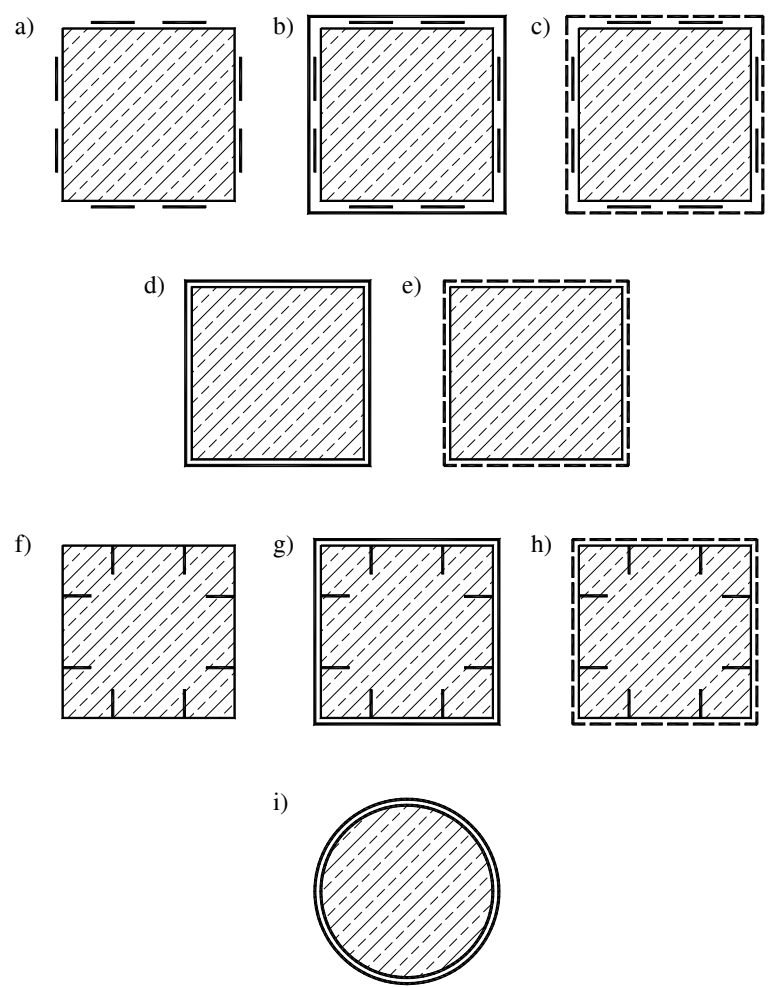

Fig 1. Proposed strengthening solutions for structural elements in compression using CFRP materials

The assumptions for strengthening structural elements in compression utilising carbon-reinforced composites are mainly based on the techniques that involve an increase of element cross-sectional area by means of adhesively bonded or bolted steel flat sections, sheet elements or brackets. The authors propose the following strengthening solutions: external adhesive bonding of longitudinal CFRP strips (Fig 1 a), external adhesive bonding of longitudinal CFRP strips and transverse CFRP band wraps (Fig 1 b), external adhesive bonding of longitudinal CFRP strips and transverse wrapping (Fig 1 c), external adhesive bonding of transverse CFRP wraps (Fig $1 \mathrm{~d}$, i), transverse wrapping (Fig $1 \mathrm{e}, \mathrm{j}$ ), internal adhesive bonding of longitudinal strips (Fig $1 \mathrm{f}$ ), internal adhesive bonding of longitudinal CFRP strips and transverse CFRP band wraps (Fig $1 \mathrm{~g}$ ), internal adhesive bonding of longitudinal CFRP strips and transverse wrapping (Fig $1 \mathrm{~h}$ ).

\section{Experimental study}

The study objective was to determine the interdependence of the intensity of external reinforcement and load-carrying capacity of the element. Reinforced concrete column models (scale 1:5) with a cross-section of $80 \times 150 \mathrm{~mm}$ and $600 \mathrm{~mm}$ high have been tested (Fig 2). 


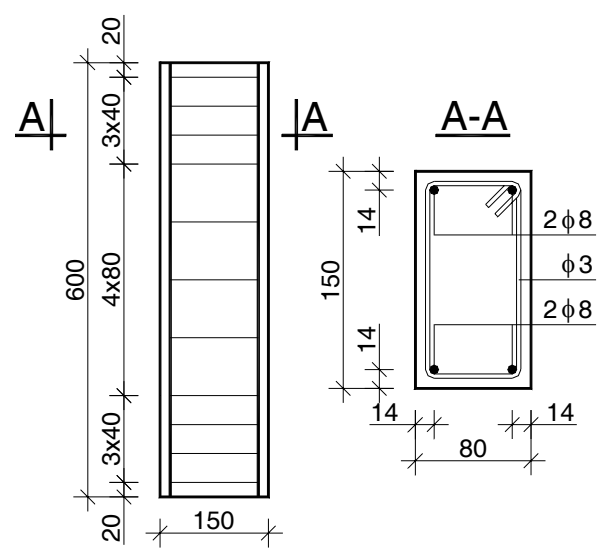

Fig 2. RC columns tested. Elements S1a and S1b

Longitudinal reinforcement consisted of four A-II (18G2) [16] steel bars with $\varnothing 8$ diameters, while transverse reinforcement was made up of A-I (St3SX) [16] steel stirrups with $\varnothing 3$ diameters. The spacing between the stirrups at the element ends was about $40 \mathrm{~mm}$ along $150 \mathrm{~mm}$ section equal to the length of the longer side of the bar cross-section. The elements were made of medium compression strength concrete $\mathrm{f}_{\mathrm{cm}}=40,8 \mathrm{MPa}$.
For achieving the designed objectives two series of elements were examined. The first series marked with "a" consisted of 5 elements with different reinforcement ratio using longitudinal CFRP strips (Fig 3). The second series with "b" consisted of 5 elements with different reinforcement intensity using longitudinal CFRP strips and external CFRP band wraps (Fig 3). External band wraps were mounted on the same level as steel stirrups.

Reinforcement ratio $\left(\rho_{\mathrm{w}}\right)$ can be expressed by the relationship between CFRP strip area $\left(\mathrm{A}_{\mathrm{L}}\right)$ and concrete cross-sectional area in the element $\left(\mathrm{A}_{\mathrm{c}}\right)$.

In addition, two control column models without reinforcement (S1a and $\mathrm{S} 1 \mathrm{~b}$ ) were examined to determine their actual load-carrying capacity and to describe the damage mechanism (Fig 2).

The following materials were used for reinforcement of elements: Sika $^{\circledR}$ CarboDur $^{\circledR}$ M1214 strengthening strips with a thickness of $\mathrm{h}=1,4 \mathrm{~mm}$ and the width adjusted to the desired reinforcement ratio, Sikadur ${ }^{\circledR}-30$, SikaWrap $^{\circledR}-230$ C, Sikadur ${ }^{\circledR}-330$ [17]. The reinforcements were applied according to the stringent technological requirements.

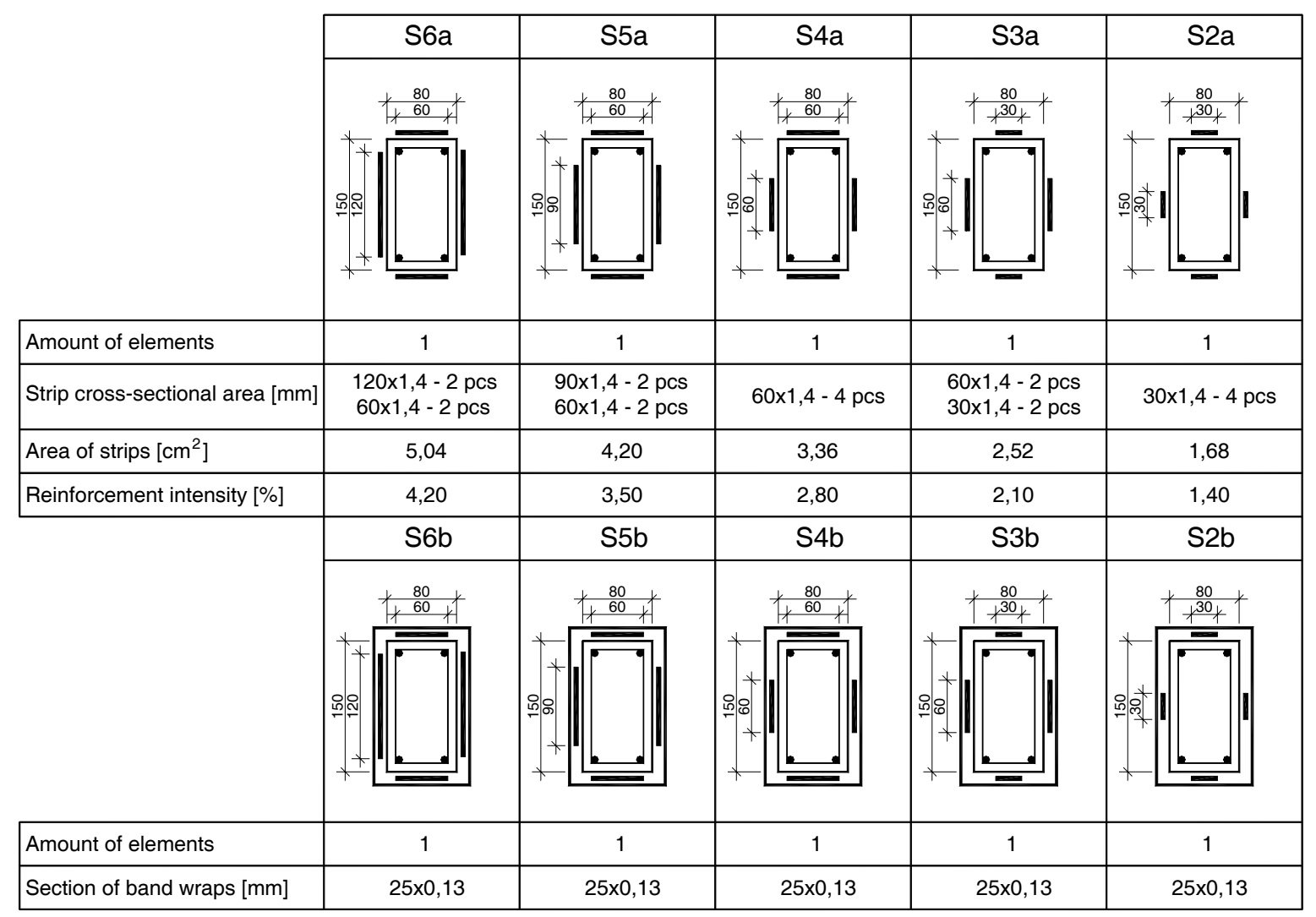

Fig 3. Main characteristics of tested specimens of series "a" and "b" 


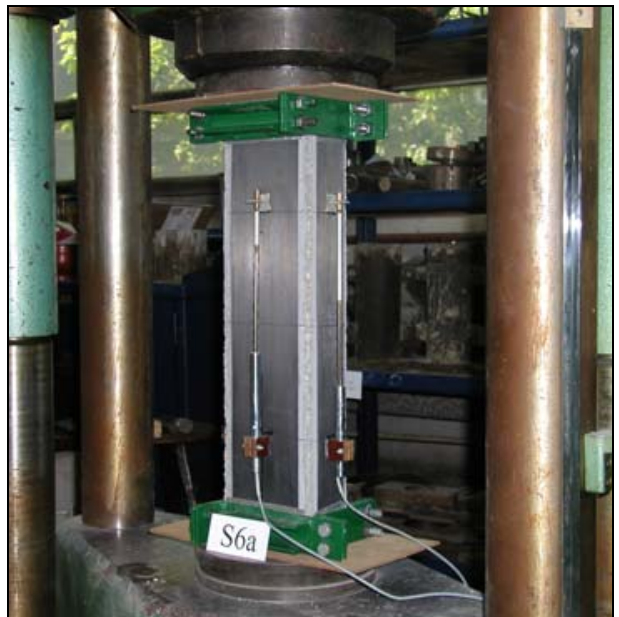

a) element S6a

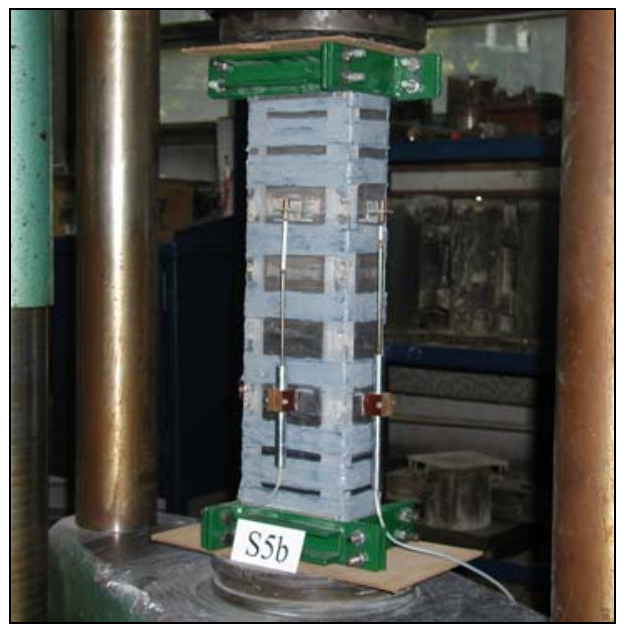

b) element $\mathrm{S} 5 \mathrm{~b}$

Fig 4. Elements during testing

Values of the material characteristics of concrete, steel reinforcement and CFRP composites are shown in Table 1.

Table 1. Mechanical properties of materials

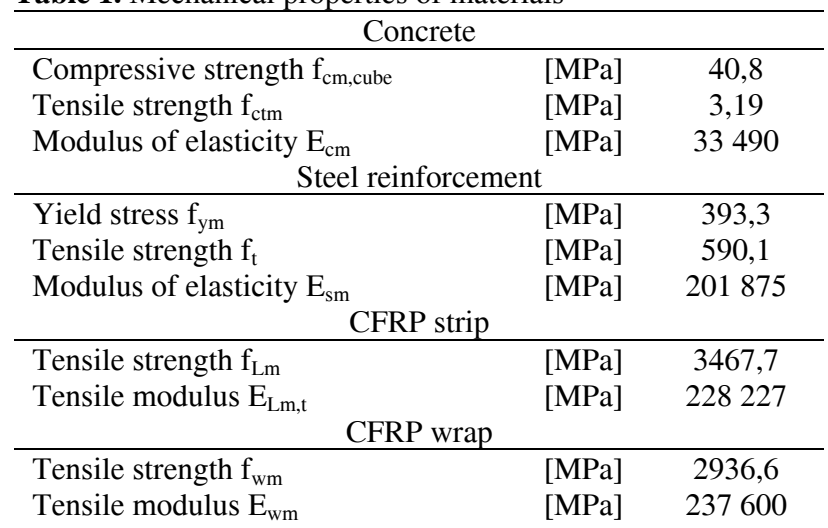

Test specimens were subjected to axial compression. The same testing programme was applied to both series, as well as to control elements. It consisted of 6 initial loading cycles (up to approx $1 / 3 \div 1 / 2$ of the boundary load-carrying capacity). The 7 th loading cycle was introduced to observe the damage mechanism. The loadings were applied step-wise according to the Polish Standard [18] requirements. Longitudinal strains were measured using sensors with accuracy of reading of $0,001 \mathrm{~mm}$.

The support area of the elements was additionally protected with steel clamping brackets to eliminate possible damage of the element caused by the piston pressure of the band press (Fig 4).

\section{Results of research}

It was found on the basis of the obtained results that the load-carrying capacity marked with S2a and S3a with the reinforcement ratio $1,40 \%$ and $2,10 \%$ respectively was not satisfactory, so they were not taken into consideration in analysis.

Figs 5 and 6 show the diagrams comparing mean longitudinal strain values $\varepsilon_{\mathrm{vm}}$ in function of the relationship of the applied loading $\mathrm{N}$ to the boundary load-carrying capacity of the elements without reinforcement $\mathrm{N}_{\mathrm{u}, \mathrm{S} 1}$ (control columns).

Fig 5 depicts the diagrams of a group of S5 type elements, while Fig 6 shows the diagrams of a group of S6 type elements. In both cases they were compared with the diagram of mean longitudinal strain values $\varepsilon_{\mathrm{vm}}$ obtained for control columns. It could be noticed in Figs 5 and 6 that the application of reinforcement using longitudinal CFRP strips improves strain abilities and load-carrying capacity by $24 \%$ for the elements S5a and S6a respectively, in comparison with control columns. The use of additional transverse reinforcement by means of CFRP band wraps prevents rapid debonding of a strip and increases load-carrying capacity by $37 \%$ and $49 \%$ for the elements S5b and S6b respectively, in comparison with control columns (Table 2).

Mean strains of the elements reinforced on the level of mean boundary load-carrying capacity of control elements are $50 \%$ less than mean longitudinal strains of the columns without reinforcement.

Distortions of the diagram S6a shown in Fig 6 are caused by the damage of the connection between the strip and the column. As a result, this produced the debonding of a strip part.

Table 2. Results of research

\begin{tabular}{lccccc}
\hline & & S1a & S4a & S5a & S6a \\
\hline Amount of elements & & 1 & 1 & 1 & 1 \\
Load-carrying capacity & {$[\mathrm{kN}]$} & 465 & 475 & 595 & 596 \\
$\begin{array}{l}\text { Vertical maximal strain } \\
\text { Growth load capacity }\end{array}$ & {$[\%]$} & 2,44 & 2,08 & 1,85 & 2,05 \\
& & & & 24 & 24 \\
& & S1b & S4b & S5b & S6b \\
\hline Amount of elements & & 1 & 1 & 1 & 1 \\
Load-carrying capacity & {$[\mathrm{kN}]$} & 500 & 595 & 657 & 712 \\
Vertical boundary strain & {$[\%]$} & 2,35 & 2,79 & 2,77 & 2,66 \\
Growth load capacity & {$[\%]$} & - & 24 & 37 & 49
\end{tabular}




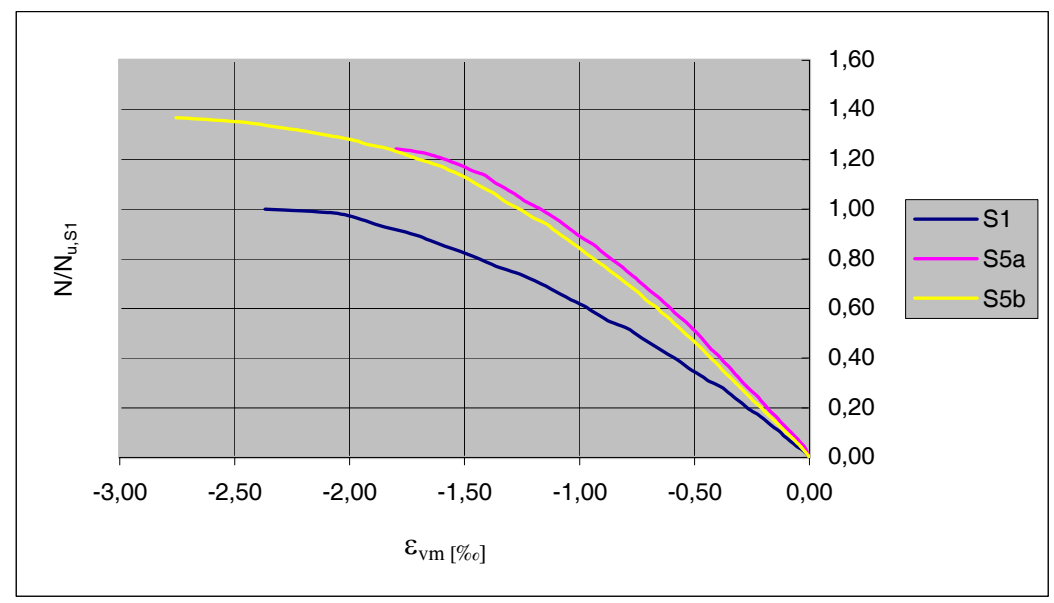

Fig 5. $\mathrm{N} / \mathrm{N}_{\mathrm{u}, \mathrm{S} 1}$ versus $\varepsilon_{\mathrm{vm}}$ for columns: $\mathrm{S} 1, \mathrm{~S} 5 \mathrm{a}, \mathrm{S} 5 \mathrm{~b}$

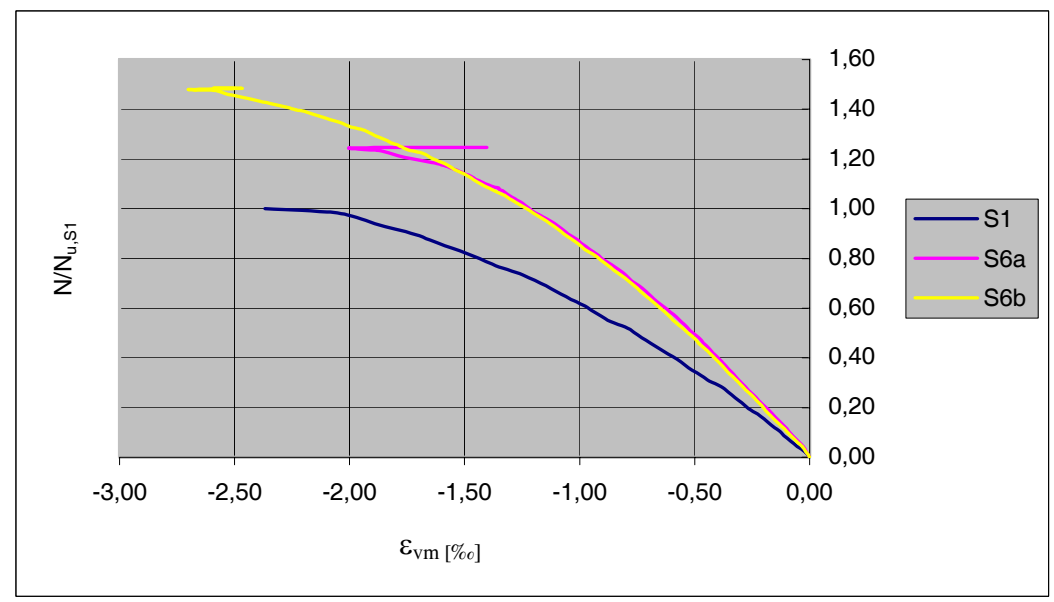

Fig 6. $\mathrm{N} / \mathrm{N}_{\mathrm{u}, \mathrm{S} 1}$ versus $\varepsilon_{\mathrm{vm}}$ for columns: $\mathrm{S} 1, \mathrm{~S} 6 \mathrm{a}, \mathrm{S} 6 \mathrm{~b}$

a) $\mathrm{S} 4 \mathrm{a}$

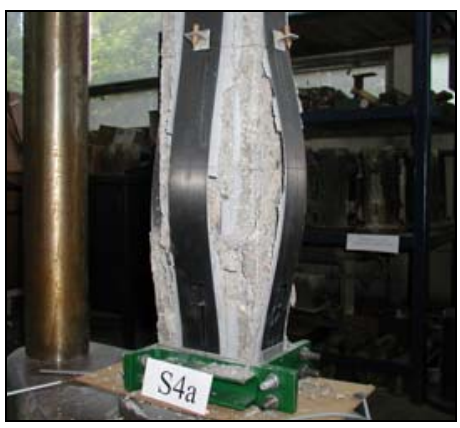

b) $\mathrm{S} 5 \mathrm{a}$

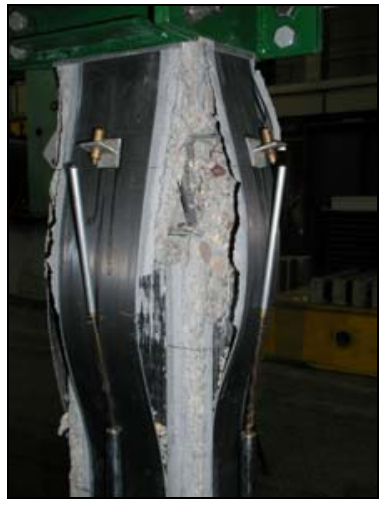

Fig 7. Damaged elements from series "a" a) $\mathrm{S} 4 \mathrm{~b}$

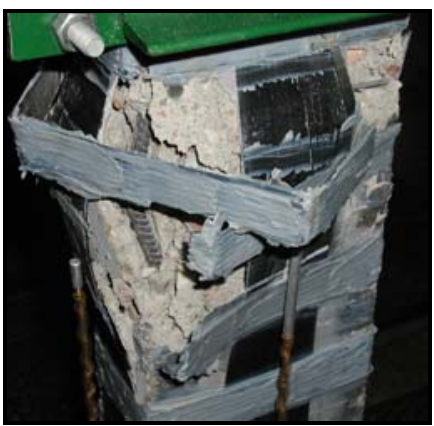

b) S6b

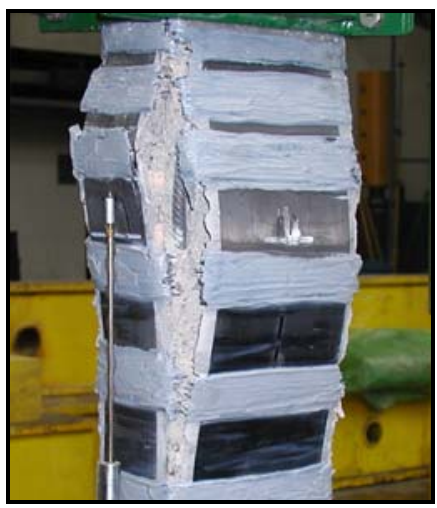

Fig 8. Damaged elements from series "b" 
Observation of the damage mechanism and evaluation of the test specimens enabled the authors to draw the following conclusion. The failure of elements from series "a" was caused by debonding a certain part of a strip, instantaneous concrete damage and steel ductility (Fig 7). Three types of debonding could be observed:

- debonding of strip with adhesive and concrete (Fig 7 a),

- debonding of strip with adhesive,

- debonding of strip only (Fig 7 b).

The failure of elements from series " $b$ " was caused by breakage of some bands and instantaneous debonding of strip, concrete damage and steel ductility (Fig 8). Breakage of bands was always preceded by cracking carbon fibres. Similar acoustic effects were observed during strength and strain test of CFRP wraps.

\section{Concluding remarks}

Results of studies confirmed that the subject was worth investigating. The application of CFRP strips to strengthen compressed elements increases their boundary load-carrying capacity. This is caused by a decrease of longitudinal strains in relation to control elements at an equal increase of longitudinal force. The use of additional external CFRP band wraps prevents debonding of a strip till the moment of the wrap breaking and the element damage.

Results of initial experimental studies aimed at describing the damage mechanism of the reinforced concrete elements in compression strengthened with CFRP show that in case of elements being strengthened only with longitudinal sections of CFRP strip, the failure was caused by the damage of the connection between the composite and the adhesive. The other reason was separation of a strip with concrete wrap from the test element. Debonded sections of the strip with concrete wrap were observed during visual inspection. They were 5-10 mm thick. Reinforced concrete columns strengthened with externally bonded CFRP strips without transverse CFRP band wraps that is subjected to compression, fail prematurely due to buckling (which causes debonding). Due to this fact the use for practical application should be made with caution. Elements reinforced with longitudinal sections of CFRP strip and additional CFRP band wraps were damaged because some bands broke, followed by instantaneous debonding of strip with concrete wrap. In this case the determining value of element load-carrying capacity is rectangular boundary strains of CFRP band wraps.

The authors plan to analyse the influence of particular components of the reinforcement, such as longitudinal strips, external band wraps and wrapping on load-capacity of elements. In order to achieve this, the following elements will be tested: elements without reinforcement, elements strengthened with longitudinal strips only, elements strengthened with longitudinal strips and external bands, elements strengthened with external bands only, elements strengthened with longitudinal strips and total wrapping and finally elements strengthened with total wrapping only. The intensity of reinforcement shall be $4,20 \%$.

The authors are fully aware of the influence for scale effects in this study. In the initial research column models were examined in the 1:5 scale. Research results need verification on elements in natural scale. The most important parameter to be taken into consideration is reinforcement ratio $(\rho w)$. Together with the growth of cross-sectional concrete in the element (Ac), the required CFRP strips will increase. Perhaps it will be necessary to use an external adhesive bonding of longitudinal and multiply CFRP strips or to limitation reinforcement intensity.

\section{References}

1. Priestley, M. J. N; Seible, F. and Fyfe, E. Column seismic retrofit using fiberglass/epoxy jackets. In: Proc of 1 st International Conference on Advanced Composite Materials in Bridges and Structures. Edited by Neale K.W. and Labossière P., Canadian Society for Civil Engineering, Montreal, Canada, 1992, p. 287-298.

2. Saadatmanesh H.; Ehsani, M. R. and Li, M. W. Strength and ductility of concrete columns externally reinforced with fiber composite straps. ACI Structural Journal, Vol 91, Issue 4, July 1994, p. 434-447.

3. Demers, M. and Neale K. W. Strengthening of existing concrete columns with unidirectional composite sheets. In: Proc of 4th International Conference on Short and Medium Span Bridges. Edited by Mufti A. A.; Bakht B. and. Jaeger L. G, Canadian Society for Civil Engineering, Montreal, Canada, 1994, p. 895-905.

4. Picher, F.; Rochette P. and Labossière, P. Confinement of concrete cylinders with CFRP. In: Proc of 1st International Conference Composites in Infrastructure. Edited by Saadatmanesh H. and Ehsani M. R., University of Arizona, Tucson, Arizona, 1996, p. 829-841.

5. Campione, G. and Miraglia, N. Strength and strain capacities of concrete compression members reinforced with FRP. Cement and Concrete Composites, Vol 25, Issue 1, 2003, p. 31-41.

6. Demers, M. and Neale, K. W. Confinement or reinforced concrete columns with fibre-reinforced composites sheets - an experimental study. Canadian Journal of Civil Engineering, Vol 26, Issue 2, April 1999, p. 226-241.

7. Li, J. and Hadi M. N. S. Behaviour of externally confined high-strength concrete columns under eccentric loading. Composite Structures, Vol 62, Issue 2, 2003, p. 145-153.

8. Rochette, P. and Labossière, P. Axial testing of rectangular column models confined with composites. Journal of Composites for Construction, Vol 4, Issue 3, Aug 2000, p. 129-136.

9. Wang, Y. Ch. Retrofit of reinforced concrete members using advanced composite materials. Research report 2000-3, Dept of Civil Engineering, University of 
Canterbury, Christchurch, New Zealand, Feb 2000. $375 \mathrm{p}$.

10. Ignatowski, P. and Kamińska, M. E. On behaviour of compressed concrete confined with CFRP composites. Engineering and Building (Inżynieria i budownictwa), No 4, 2003, p. 204-208 (in Polish).

11. Ignatowski, P. and Kamińska, M. E. On the effect of confinement of slender reinforcement concrete columns with CFRP composites. International Journal for Restoration, Vol 10, No 1, 2004, p. 7398.

12. Kamiński, M. and Trapko, T. Research methodic on compression of reinforced concrete elements strengthened with CFRP strips and wraps. In: Transactions in Building Materials and Engineering Structures (Praca zbiorowa „Badanie materiałów budowlanych i konstrukcji inżynierskich"). Ed by Kamiński M., Kmita A., Łodo A., Michałek J., Chapter 3.5, Dolnośląskie Wydawnictwo Edukacyjne, Wrocław, Poland, 2004. 484 p. (in Polish).

13. Trapko, T. Research on load-carrying capacity of reinforced concrete columns strenghtened with CFRP strips and wraps. In: Proc of 4th PhD Symposium in Civil Engineering (IV Konferencja Naukowa Doktorantów Wydziałów Budownictwa), Gliwice Wisła, Poland, 2003, p. 425-432 (in Polish).

14. Trapko, T. Theoretical models for dimensioning of RC columns strengthened with FRP composite products. In: Proc of 5th PhD Symposium in Civil Engineering (V Konferencja Naukowa Doktorantów Wydziałów Budownictwa), Gliwice - Wisła, Poland, 2004, p. 525-534 (in Polish).

15. Trapko, T. Load capacity of RC columns strengthening with CFRP strips and wraps (Nośność żelbetowych słupów wzmacnianych taśmami i matami $\mathrm{z}$ włókien węglowych). $\mathrm{PhD}$ thesis, report series PRE 22/04, Institute of Building Engineering, Wroclaw University of Technology, Wroclaw, Poland, 2004 (in Polish).

16. PN-B-03264:2002. Polish Standard: Plain, reinforced and prestressed concrete structures. Analysis and structural design. (Konstrukcje betonowe, żelbetowe i sprężone. Projektowanie i obliczenia statyczne). Polish Committee for Standardization, Warsaw, Poland, 2002. 142 p. (in Polish).

17. Technical approval Road and Bridge Research Institute, No AT/2003-04-0336 (Aprobata techniczna IBDiM No AT/2003-04-0336), 2003. 18 p. (in Polish).

18. Polish Standard PN-73/B-06281 Precast concrete unit. Methods of strength testing (Prefabrykaty budowlane $\mathrm{z}$ betonu. Metody badań wytrzymałościowych). Polish Committee for Standardization, Warsaw, Poland, 1973. 8 p. (in Polish).

\section{ANGLIES PLUOŠTU ARMUOTO POLIMERO LAKŠTAIS SUSTIPRINTŲ GELŽBETONINIŲ KOLONŲ EKSPERIMENTINIS TYRIMAS}

\section{Kamiński, T. Trapko}

Santrauka

Gelžbetoninių konstrukcijų stiprinimas - vienas iš sudètingiausių ir svarbiausių statybinių konstrukcijų srities uždavinių. Straipsnyje nagrinejama gelžbetoninių konstrukcijų stiprinimo problema. Čia pateikti anglies pluoštu armuoto polimero lakštais (CFRP) sustiprintų gelžbetoninių kolonų laikomosios galios eksperimentinių tyrimų rezultatai. Pirmasis tyrimų tikslas - nustatyti armatūros rūšies įtaką laikomajai galiai ir deformacijoms. Antrasis tikslas - nustatyti priklausomybę tarp išorinès armatūros intensyvumo ir elemento laikomosios galios. Bandymų rezultatai parodè tyrimų svarbą. Taip pat išnagrinèta priklausomybè tarp išorinės armatūros procento ir nedidelių gelžbetoninių kolonų su skirtingais armavimo procentais (nuo 1,4\% iki 4,2 \%) laikomosios galios.

Reikšminiai žodžiai: kolona, gniuždymas, laikomoji galia, sustiprinimas, CFRP.

Prof PhD Eng Mieczysław KAMIŃSKI. Chief of Division of Concrete Structures part of Institute of Building Engineering at Wroclaw University of Technology, Poland. Member of fib (International Federation for Structural Concrete), IABSE (International Association for Bridge and Structural Engineering). His main research areas include silo structures (both reinforced and pre-stressed), cooling towers and use of CFRP materials for strengthening constructions.

PhD Eng Tomasz TRAPKO. Assistant of Division of Concrete Structures part of Institute of Building Engineering at Wroclaw University of Technology, Poland. His research includes repairs of concrete structures and use of CFRP materials for strengthening constructions. 